\title{
As funções do Juízo final como imagem religiosa
}

The functions of the Last Judgement as religious image

Tamara QUÍRICO•

Resumo: $\mathrm{O}$ uso de imagens como fonte histórica vem sendo motivo de debate há algumas décadas. O presente artigo visa a defender a sua importância uma vez que, por possuírem origem diversa das fontes escritas, as fontes visuais permitem perceber outras formas de manifestação da vida social, assim como novos atores sociais. O texto concentra a análise em representações visuais do tema do Juízo final realizadas na Idade Média, buscando um melhor entendimento não somente da religiosidade, como também da própria história das sociedades que criaram essas imagens. Neste artigo serão discutidos os modos de compreensão de pinturas sobre o Juízo final no período medieval, assim como as funções esperadas para esse tipo de imagem. A análise se concentrará particularmente nos exemplos italianos pintados entre os séculos XII e XIV.

Palavras-chave: Juízo final; Função das imagens; Arte medieval.

\begin{abstract}
The use of images as historical sources has been reason for debate for some decades. The current article aims to defend its importance since they own diverse origin from the written sources, the visual sources allow us to realize other ways of manifestation of the social life, as well new social actors. The text concentrates the analysis in visual repesentations of the topic of the Last Judgement performed in the Middle Age, seeking a better understanding not only of the religiousness, but also own history of the societies that created these images. Forms of understanding the paintings about the Final Judgement in the medieval period will be discussed in this article, as well the functions expected for this kind of image. The analysis will be found particularly in the Italian examples painted between XII and XIV centuries.
\end{abstract}

Keywords: Final Judgement; Function of the images; Medieval art.

Homo, memento finis, et in aeternum non peccabis.

$(\operatorname{Ecl} 7,36)$

Ao menos desde o século XVI os historiadores questionam o problema do uso de imagens e objetos, considerados atualmente como artísticos, para a construção do conhecimento histórico. A visão tradicional era a de que a escrita seria sempre o foco primordial; os chamados "textos figurativos" se limitariam a copiar desses escritos os temas, e os interpretariam a partir das orientações fornecidas unicamente por eles. Se ao menos até as primeiras décadas do século XX as imagens eram entendidas especialmente como complemento, uma forma de corroborar uma informação advinda de uma fonte escrita, atualmente já se percebe o uso potencial dessas mesmas imagens; entende-se que é possível compreender melhor a história através de objetos artísticos objetos admirados e analisados na atualidade principalmente por suas qualidades estéticas -, uma

\footnotetext{
- Historiadora da Arte - Doutora em História Social - IPHAN - Instituto do Patrimônio Histórico e Artístico Nacional Rua da Imprensa, 16 - sala 910, CEP: 20030-120, Rio de Janeiro, Rio de Janeiro, Brasil. E-mail: tquirico@gmail.com
} 
vez que se percebe que esse objeto é um fato social construído. Abre-se o campo, desse modo, para outras fontes de conhecimento histórico.

As fontes visuais devem ser incluídas, portanto, entre as fontes historiográficas essenciais; por possuírem origem diversa das fontes escritas, elas permitem perceber outras formas de manifestação da vida social, assim como novos atores sociais. Isto revela a diversidade das experiências possíveis; é o que permite reconhecer que as sociedades são caracterizadas por diferentes tipos de expressão, que indicam, por sua vez, a multiplicidade desses mesmos atores sociais. O uso de outras fontes permite, enfim, que se reconheça a mudança do caráter do discurso em função do meio pelo qual é expresso; possibilita que se tenha não uma visão completa, mas uma noção menos fragmentada de uma determinada sociedade. Como escreve o historiador inglês Peter Burke, “pinturas, estátuas, publicações e assim por diante permitem a nós, posteridade, compartilhar as experiências não-verbais ou o conhecimento de culturas passadas” (BURKE, 2005, p.16-17). A questão do uso das imagens, portanto, vem se tornando cada vez mais importante nas discussões históricas.

Uma suposta prevalência das imagens sobre outras formas de manifestações culturais a partir do século XX vem justificando o desenvolvimento de um novo campo de pesquisa denominado estudos visuais ou cultura visual, cujo enfoque residiria principalmente na cultura de massa do século XX e do início do XXI, em particular a partir da década de 1960. Embora os autores que trabalham nesse campo não excluam a priori a produção de imagens de outras épocas - basta mencionar que o autor que de certo modo inaugura o campo, Michael Baxandall, analisa a produção pictórica da Itália do século XV -, o modo como esse campo é discutido não parece dar margem à inclusão dessas imagens.

Apesar do enfoque contemporâneo dado pela maior parte desses autores, é possível aplicar ao menos algumas das análises por eles propostas para imagens de outros períodos históricos novamente, o texto mesmo de Baxandall parece corroborar essa ideia. Nos casos em discussão pelo presente artigo, obras com o tema do "Juízo final” poderiam em última instância ser consideradas uma grande forma não somente de ilustração, mas também de difusão da doutrina cristã: seja um bom cristão e receba como recompensa as benesses do Paraíso; peque e veja na obra as futuras consequências de seus atos...

A adequada percepção de uma imagem estará sujeita, sem dúvida, ao momento histórico em que ela estará sendo discutida. Não se pode esperar que uma mesma imagem seja percebida de igual modo por um cristão do século XIV e por um cristão do século XX. De modo análogo, a sua compreensão dependerá não somente de como será vista, mas igualmente de quem a vê - ou 
melhor, dos conhecimentos prévios que aquele que vê a imagem possui. Sendo assim, um cristão do século XIV necessariamente compreenderá uma pintura religiosa de forma diversa de um muçulmano do mesmo período. Como escreve Richard Leppert,

Os observadores são participantes ativos na determinação do significado. Para 'ver' (isto é, 'perceber'), tenho de conhecer algo. No nível mais básico isto requer que eu reconheça o que estou vendo, embora o mero reconhecimento não me leve longe (LEPPERT, 1996, p.6).

Comentam ainda acertadamente Sturken e Cartwright que "significados são afetados pela orientação social do observador e pelo contexto em que se vê" (STURKEN; CARTWRIGHT, 2001, p.47). Tome-se como exemplo o ciclo com o tema do Juízo final de Taddeo di Bartolo, executado por volta de 1393 (Figura 1): ele ganha, com efeito, em sentido quando visto em seu contexto original, no interior da Collegiata de San Gimignano, onde ocupa a parede interna da fachada, bem como as duas paredes da nave, fechadas originalmente em uma capela. A escala monumental da obra intensifica o impacto sobre o observador. Ademais, a imagem do Juízo final será melhor compreendida em relação ao resto da decoração da igreja; essa narra, efetivamente, toda a história cristã com afrescos representando cenas do Antigo e do Novo Testamentos.
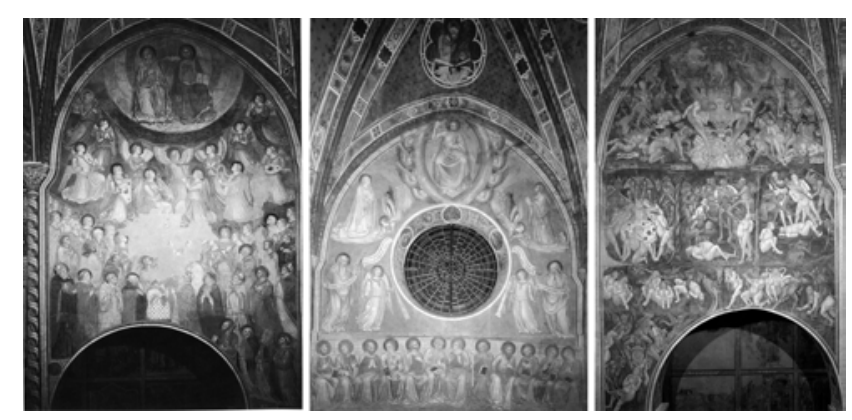

FIGURA 1 - Taddeo di Bartolo. Paraíso, Juizo final, Inferno, ca. 1393. San Gimignano, Collegiata. Procedência da fotografia: IMBERCIADORI, J.V., e TORRITI, M. La Collegiata di San Gimignano. Poggibonsi: Nencini, s/d. Montagem da autora.

Essa concepção da igreja como microcosmos surgiu primeiramente em Bizâncio. Esse fato se relacionava diretamente à decoração do espaço sagrado, como explica com precisão André Grabar:

Este tipo de decoração foi planejado para igrejas de planta centrada com uma cúpula central. E assim como estas eram concebidas como microcosmos, reproduções em escala reduzida do Cosmos, também as pinturas nas paredes e abóbadas eram projetadas segundo um plano sistemático para a instrução dos fiéis. $\mathrm{Na}$ cúpula e em sua subestrutura eram mostradas as mais santas figuras do mundo invisível; no coro, os mistérios sagrados pertencentes ao mesmo mundo tornados inteligíveis; em abóbadas secundárias e paredes, os eventos da vida de Cristo na terra, correspondendo aos diversos estágios da redenção do homem, de que a Missa solenizada na igreja era testemunha. Esta ilustração iconográfica da Missa era parte 
de uma disposição plástica do Universo Ideal e correspondia a uma noção cara aos bizantinos - de que a liturgia da Igreja não era mais do que um correlativo terreno da interminável Missa solenizada no céu pelos anjos, que, apenas após a redenção da humanidade pelo Verbo tornado Carne, poderia tornar sua natureza conhecida ao homem. Portanto os ciclos dos Evangelhos representados nas igrejas bizantinas medievais eram lembretes do retorno do homem à união com Deus e do direito que ele possuía de um lugar no Universo de Deus, como representado em cada igreja (GRABAR, 1953, p.26).

Neste contexto, não é difícil perceber a importância do Juízo final, que encerra a história do universo e do homem, propiciando, como escreve Grabar, o retorno desse homem à união com Deus - ou à condenação eterna, privado dessa mesma união.

Essa noção apenas explicada por Grabar, como se pode inferir, foi também assimilada e adaptada pela tradição ocidental. Assim, o ciclo de Taddeo di Bartolo em San Gimignano conclui, conforme apenas comentado, o programa decorativo da Collegiata, os ciclos de afrescos com a temática do Antigo e do Novo Testamentos, que haviam sido realizados anteriormente por Barna da Siena e Bartolo di Fredi nas paredes da nave. O ciclo de San Gimignano, decerto, faz parte de uma tradição italiana em que há essa inter-relação na decoração do espaço sagrado culminando com a representação do Juízo final. O mesmo ocorre com o afresco da Basílica de Sant'Angelo in Formis, realizado por volta de 1080 (Figura 2), e também com o afresco de Giotto na Capela Scrovegni, em Pádua, pintado entre 1305 e 1307 (Figura 3). No primeiro caso há, assim como em San Gimignano, a sequência de cenas do Antigo e do Novo Testamentos; no segundo, narram-se as vidas da Virgem e do Cristo. Não há a representação do Antigo Testamento - embora, segundo Giorgio Segato, as histórias de São Joaquim e Santa Ana no início do ciclo resumissem todas as histórias veterotestamentárias ${ }^{1}$; a cena do Juízo final, porém, se apresenta da mesma forma como a conclusão lógica para as histórias narradas nas paredes laterais da capela - que, no caso específico da vida de Cristo, são as próprias cenas do Novo Testamento, narradas até o episódio de Pentecostes ${ }^{2}$. 


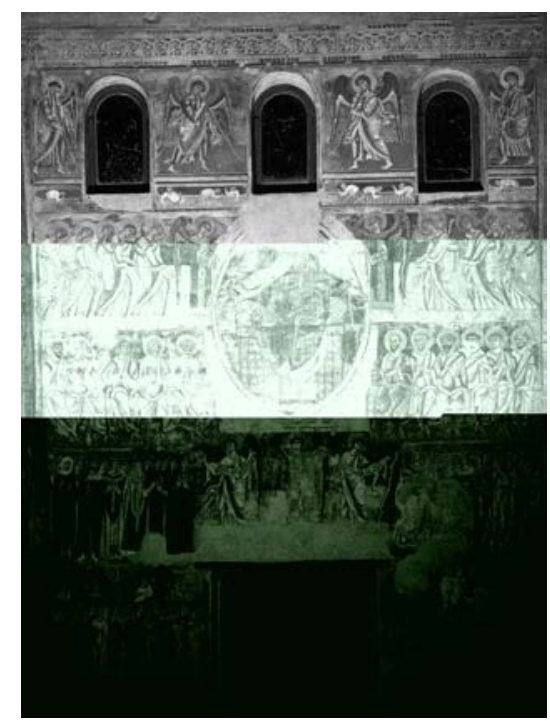

FIGURA 2 - Juizo final, ca. 1080. Sant'Angelo in Formis, Basílica. Procedência da fotografia: CHRISTE, Y. Il Giudizio universale nell'arte del Medioevo (trad. Maria Grazia Balzarini). Milão: Jaca Book, 2000

Para uma plena compreensão de uma imagem com o tema do Juízo final no interior de uma igreja ou de outro edifício - embora essa discussão pudesse ser estendida a qualquer imagem religiosa - é preciso, portanto, que o observador possua conhecimentos básicos sobre a doutrina e a exegese cristãs, e também sobre as histórias bíblicas, de modo a poder reconhecer nas paredes as cenas retratadas e compreender que o Juízo final fecha esse ciclo narrativo mais amplo. É importante, ademais, conhecer a localização original da representação que se observa e sua relação com outras imagens a ela próximas - o que é essencial quando a imagem em questão é uma pintura ou escultura colocadas em um museu, retiradas, portanto, de seu contexto original. Deve-se ter em conta, desse modo, o programa iconográfico que provavelmente teria sido concebido na origem, e não as fragmentações posteriores e/ ou deslocamentos para outros locais que não o original.

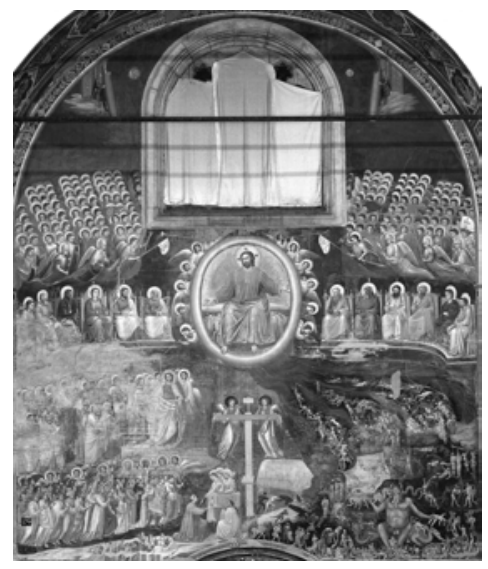

FIGURA 3 - Giotto di Bondone. Juizo final, 1305-1307. Pádua, Capela Scrovegni. Procedência da fotografia: CHRISTE, Y. Il Giudizio universale nell'arte del Medioevo (trad. Maria Grazia Balzarini). Milão: Jaca Book, 2000 
Desse modo, é preciso ter em conta que as expectativas com relação às funções de representações com o mesmo tema poderiam variar bastante de acordo com seu posicionamento dentro de um edifício, assim como é necessário investigar igualmente as especificidades dos locais em que são realizadas as pinturas. Ou seja, não basta saber em que lugar do edifício elas se encontram, mas também em que tipo de edifício elas foram executadas. O tema do Juízo final, de fato, foi representado em locais tão diversos como catedrais, igrejas abaciais, paróquias, collegiate, batistérios, capelas - sejam públicas ou privadas -, capelas funerárias, capelas palacianas e mesmo cemitérios e túmulos individuais; e não podem ser esquecidos os inúmeros painéis que, além de em qualquer um desses edifícios, poderiam estar também nas residências dos fiéis. Uma vez mais, as possibilidades de funções poderiam se alterar conforme o tipo de edifício a que se destinava a imagem.

Deve-se considerar, por fim, que essas obras serão apenas compreendidas em sua totalidade se o observador conhecer a situação religiosa da Toscana dos séculos XII ao XIV; será possível, assim, compreender de forma mais adequada as funções desempenhadas por esse tipo de imagem nessa cultura específica. Conforme comentado, as percepções dessas imagens hoje, sem dúvida, diferem largamente dos modos de assimilação das mesmas no Trecento. Compreender melhor a imagem, enfim, significa conhecer melhor a história que a produziu.

Especificamente com relação ao tema tratado aqui, é necessário, ademais, ter um domínio da iconografia do Juízo final de modo geral, assim como dos diferentes tipos iconográficos acrescentados à estrutura inicial desse tema ao longo do tempo. Deve-se ressaltar, no entanto, que aquele que não compreende a iconografia do Juízo final, seu significado e sua importância no contexto religioso cristão, particularmente durante a Idade Média e mais ainda para a Toscana do período, ainda assim poderá ser capaz de apreciar a obra por suas qualidades artísticas; a apreciação estética, em um nível mais básico, independe, de fato, do significado mesmo da obra. O apreciador não poderá, entretanto, ir além disso, pois a obra possui uma significação fundamental que só pode ser encontrada fora de si própria. Uma pintura de uma mulher com uma criança no colo pode, com efeito, ser admirada por suas qualidades estéticas, pela delicadeza da pincelada, pela beleza do desenho; essa mesma pintura, entretanto, ganha enormemente em significação quando se reconhecem nas personagens a Virgem Maria e o Menino Jesus, mesmo que o observador não seja cristão ou esteja inserido nessa tradição cultural judaico-cristã. As imagens criadas pelo homem ao longo de sua trajetória são parte de toda uma tradição, não podendo ser plenamente compreendidas sem um conhecimento dessa mesma cultura. "Para interpretar a mensagem, é necessário familiarizar-se com os códigos culturais", afirma Burke (2002, p.46). Sem um conhecimento dessa tradição religiosa cristã, a Última ceia de Leonardo torna-se apenas mais uma cena de banquete, ou de um jantar entre amigos. 
Mesmo quem reconhecesse o tema, porém, poderia estar limitado na compreensão plena da obra. Na Idade Média, com efeito, defendia-se a existência de quatro níveis possíveis de leitura e de interpretação de uma mesma imagem ou de um texto: o literal, o alegórico, o moral e o anagógico. Esses quatro níveis já eram empregados pelos primeiros Padres da Igreja para explicar os quatro significados interpretativos possíveis das Escrituras; eles podem, entretanto, ser aplicados também não somente a outros textos como a imagens, particularmente quando estas estivessem acompanhadas de epígrafes. A capacidade de ir além das leituras mais básicas dependeria, decerto, do nível de instrução do observador - o que corroboraria a definição de Sturken e de Cartwright de que a compreensão de uma imagem estaria diretamente relacionada à "orientação social" desse observador, especialmente no período medieval.

Pode-se indagar quais seriam os objetivos dessas obras. Toda imagem religiosa possui funções particulares. No período medieval elas difundiam os princípios religiosos das sociedades, doutrinando aqueles que não conseguiriam ter acesso a outras fontes de conhecimento. Uma noção que encontra respaldo na máxima de São Gregório Magno difundida no século VII, e que nortearia a compreensão da arte medieval:

[...] o que a escrita é para os que sabem ler, a pintura é para os iletrados que a vêem, pois nela os ignorantes vêem aquilo que devem seguir; nela lêem aqueles que desconhecem as letras. Assim, especialmente para os gentios, uma pintura toma o lugar da leitura (DUGGAN, 1989, p.227-228, nota 01). ${ }^{3}$

A discussão sobre a importância das imagens no contexto religioso, seguindo as indicações de Gregório Magno, é retomada continuamente ao longo de todo o período medieval, sem grandes modificações com relação ao que afirmara o papa na virada do século VI para o VII ${ }^{4}$. No século XIII, há dois autores de capital importância que discutiram o papel da arte religiosa: São Boaventura e Santo Tomás de Aquino. Boaventura, em seus comentários às Sentenças de Pedro Lombardo, definiu três funções para essa arte. Elas poderiam, primeiramente, instruir, pois foram feitas "para a simplicidade dos ignorantes"; poderiam despertar a devoção dos fiéis, "pois nossa emoção é despertada mais pelo que é visto do que pelo que é ouvido"; as imagens, por fim, atuariam diretamente na memorização de fatos, "pois aquilo que é somente ouvido é esquecido mais facilmente do que aquilo que é visto"5. As definições de Boaventura são assaz próximas às de Tomás de Aquino que, comentando a mesma passagem das Sentenças, defende também o triplo uso das imagens: 
Houve três razões para a instituição de imagens nas igrejas. Primeiro, para a instrução das pessoas simples, porque podem ser instruídas por elas como que por livros. Segundo, de modo que o mistério da Encarnação e os exemplos dos santos possam estar mais ativos em nossa memória em função de estarem sendo representados diariamente para nossos olhos. Terceiro, para excitar sentimentos de devoção, esses sendo despertados mais efetivamente por coisas vistas do que por coisas ouvidas. ${ }^{6}$

Também Gregório, de resto, destacava em sua carta de 600 a possibilidade de uma pintura poder despertar sentimentos de devoção, embora esses sentimentos, para ele, devessem necessariamente ser dirigidos à "Trindade onipotente e santa" (Apud CHAZELLE, 1990, p.140)7. Boaventura e Tomás de Aquino, como visto, não limitam nesse ponto o papel das imagens, e se pode inferir a possibilidade de uma pintura despertar sentimentos devotos vários, seja direcionados para a Trindade como para um santo eventualmente representado na cena ${ }^{8}$.

Essa questão terá particular importância no Purgatorio da Commedia de Dante Alighieri. A montanha do Purgatório é estruturada em terraços, nos quais os penitentes vão subindo gradativamente de acordo com sua purificação, até que sejam, enfim, conduzidos ao Paraíso. Nesses terraços há imagens que apresentam a narrativa bíblica de forma esculpida, pintada ou iluminada em manuscritos, e que funcionariam como textos visuais para os penitentes. Para Dante, portanto, o desenvolvimento espiritual desses penitentes aconteceria em resposta a essas narrativas visuais ${ }^{9}$.

Pode-se criticar a máxima de São Gregório Magno, considerando que as imagens medievais poderiam ser excessivamente complexas para que fossem compreendidas de forma adequada por um povo rude e iletrado. Devido a essa complexidade, esses observadores não seriam capazes de ir além do significado literal daquela determinada imagem. Deve-se, porém, ter em conta o que recorda Burke (2005, p.60):

Tanto a iconografia quanto as doutrinas que ela ilustrava poderiam ter sido explicadas oralmente pelo clero, a imagem em si agindo como um lembrete e um reforço da mensagem falada, em vez de se constituir em uma única fonte de informação ${ }^{10}$.

Sem dúvida, um ponto que deve ser constantemente frisado ao se discutir o papel das imagens na instrução dos fiéis leigos é o fato de que elas seriam capazes de atuar plenamente apenas aliadas a uma outra base de formação. Elas funcionariam como lembretes, mas os leigos só poderiam ser lembrados daquilo que já conhecessem. Esse fato, em verdade, já estaria indicado também na segunda carta de São Gregório ao bispo Serenus, ao escrever que as imagens "foram feitas para a edificação das pessoas ignorantes, de modo que os ignorantes das letras que contemplarem essas histórias possam aprender o que lhes foi dito" (Apud CHAZELLE, 1990, p.243) ${ }^{11}$. As histórias, portanto, já lhes teriam sido ensinadas, ou em um momento anterior ou simultaneamente à ação de 
contemplar as imagens. Imagens não podem trazer, por si só, novas informações compreensíveis ao público. Como destacado anteriormente, sem um conhecimento prévio a Última ceia de Leonardo se tornaria incompreensível em seu pleno significado religioso. Uma representação do Juízo final seria somente um amontoado de corpos ao redor de uma figura central. É o que explica Gombrich com relação a um relevo representando o martírio de São Lourenço:

Sem a ajuda da palavra falada, os iletrados, é claro, não poderiam saber que o sofredor não é um malfeitor mas um santo marcado pelo símbolo da auréola, ou que os gestos feitos pelos observadores [da cena] indicam compaixão. Porém, se a imagem por si só não poderia contar ao fiel uma história de que ele jamais havia ouvido falar, ela era admiravelmente adequada para recordá-lo de histórias que lhe haviam sido contadas em sermões ou lições (Apud DUGGAN, 1989, p.243).

Para preencher as lacunas que a população leiga e iletrada certamente teria com relação à exegese cristã, haveria religiosos para esclarecerem didaticamente as dúvidas, o que seria melhor realizado com o apoio das imagens.

É necessário, entretanto, destacar outra questão. A partir do século XII começou a aumentar de forma consistente o número de leigos alfabetizados. Para o clero, no entanto, a capacidade de leitura dos leigos não seria suficiente para permitir a compreensão adequada do texto; para tanto, as imagens continuariam desempenhando um papel primordial. É nesse sentido, provavelmente, que Honório de Autun, nessa época, reformulando a sentença de Gregório Magno, escreveria que as imagens, nas igrejas, funcionariam como laicorum litteratura, literatura dos leigos, substituindo, desse modo, illiterati por laici (Cf. DUGGAN, 1989, p.231). Acreditava-se na época, portanto, que não bastaria saber ler; a interpretação adequada das Escrituras requeria uma cultura religiosa inacessível ao leigo, que continuaria necessitando não somente das imagens, mas também do apoio de um religioso que poderia traduzi-la de forma correta ao homem comum. Tanto letrados como iletrados, então, continuariam sendo ensinados por meio de ensinamentos orais, respaldados, corroborados e frisados por meio das imagens que se referissem ao mesmo tema em discussão.

A questão da necessidade de um religioso para a adequada compreensão parece explícita em Santo Tomás de Aquino que, ao discutir as funções esperadas de uma imagem, enfatiza o fato de que os leigos podem ser instruídos pelas imagens como pelos livros. O santo não afirma, em momento algum, que eles seriam capazes de ler e compreender as imagens por si só. Santo Tomás coloca os leigos, portanto, de forma passiva diante das imagens, necessitando de um religioso que os guie na interpretação correta do tema (Cf. DUGGAN, 1989, p.232).

Deve-se ter em conta, por outro lado, que mesmo os iletrados estariam já habituados a essas imagens religiosas, uma vez que não apenas participariam desde cedo das missas, como ouviriam frequentemente as pregações dos religiosos pelas ruas e praças da cidade, que se intensificaram 
graças ao trabalho das ordens mendicantes a partir do século XIII. Particularmente com relação ao tema do Juízo final, deve-se recordar que muitos desses pregadores enfatizavam constantemente a necessidade de arrependimento porque o fim dos dias estaria se aproximando, e ao menos um deles - o dominicano Jacopo Passavanti - descreveu em detalhes, no século XIV, não somente o julgamento final, como especialmente as punições infernais. Mesmo para um iletrado, portanto, os significados fundamentais da imagem poderiam eventualmente ser compreendidos sem grande dificuldade, uma vez que já teriam sido traduzidos e explicados em outros momentos.

É preciso considerar, ademais, outro ponto. Muitos dos elementos incorporados a essas imagens possuem um apelo popular bastante forte; isso não apenas atrairia mais a atenção do fiel, como facilitaria, sem dúvida, a compreensão da cena, uma vez que o observador estaria já familiarizado com esses elementos. Para citar um exemplo, pode-se mencionar a cena da psicostasia (Figura 4), tema recorrente nas representações do Juízo final ao longo da Idade Média, mas que não conheceu uma difusão equivalente nos exemplos italianos do mesmo período. A psicostasia sintetiza de modo claro, evidente e inequívoco toda a mensagem do tema do Juízo final: o julgamento - a pesagem das boas ações contra aquelas más - está claramente enunciado; a inclusão, bastante usual, de pequenos demônios tentando deturpar o resultado final do julgamento acentua o caráter perverso do mal, incentivando os fiéis a permanecerem no caminho do bem ${ }^{12}$. As imagens, de qualquer modo, apenas em poucos casos poderiam atuar sozinhas. De modo geral, sua significação, sem dúvida, será totalmente alcançada apenas se o observador for capaz de ir além da própria obra. A imagem não pode, de fato, ser estudada de modo pleno sem a escrita.

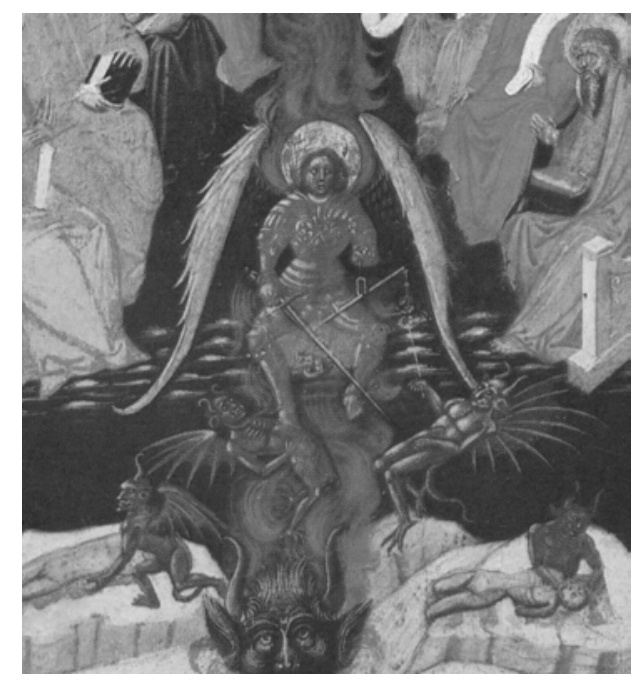

FIGURA 4 - Anônimo bolonhês. Juízo final, detalhe da psicostasia, século XIV. Bolonha, Pinacoteca Nazionale. Procedência da fotografia: GRUBB, N. Revelations. Art of the Apocalypse. Nova York:

Abbeville, 1997 
Decerto, é plausível especular sobre uma relação entre um texto e uma imagem que trate do mesmo tema; a partir do século XIII, a ligação poderia ser realizada entre as imagens e as pregações - vide o exemplo apenas mencionado de Jacopo Passavanti e sua descrição do Juízo final - e as laudas. Tanto essas pregações como as laudas visavam a um público leigo - um público mais amplo, portanto - e por isso tratavam dos temas não apenas em língua vernácula, de fácil compreensão, mas também de forma mais patética, buscando uma emotividade do público que as ouvisse. Em alguns casos é possível, de fato, estabelecer de modo claro essas relações. Especificamente sobre as laudas, o historiador da arte italiano Pietro Scarpellini desenvolve essa analogia em um artigo dedicado particularmente às representações - visuais e literárias - da Paixão de Cristo ${ }^{13}$. No entanto, como nota o próprio Scarpellini, é “ilusório esperar encontrar textos figurativos onde seja possível instituir uma precisa, unívoca relação de dependência com um texto literário ou vice-versa" ${ }^{\prime 4}$, uma vez que cada meio expressivo possui formas de desenvolvimento particulares; deve-se considerar, ademais, que não existe uma única fonte da qual se poderia tirar inspiração para a realização da obra. "O caso de um afresco, de uma tela, de um painel que traduzam pontualmente, fielmente, os temas de uma lauda em formas visíveis, que resultariam em quase um equivalente preciso, talvez não exista, como não existe o contrário" ${ }^{\text {"15 }}$.

Uma imagem, portanto, dificilmente poderá ser considerada a ilustração - ou tradução precisa de um texto específico. Deve-se notar por fim que Scarpellini chama a atenção para outro ponto preciso: é difícil - se não praticamente impossível - na maior parte dos casos estabelecer a "paternidade", a origem de um motivo que será desenvolvido tanto nos textos como nas imagens.

No caso específico da elaboração de uma representação visual do Juízo final, a questão é ainda mais complexa: com efeito, é preciso levar em consideração o fato de que, embora seja um dos temas de maior importância para os cristãos, não há um texto único que sirva de base para a descrição da cena, e, desse modo, para o desenvolvimento iconográfico do tema. Daí deriva a primeira complexidade: há fontes textuais variadas, muitas vezes extremamente diversas entre si, a partir das quais é possível criar uma única imagem ${ }^{16}$. Ademais, a iconografia desse tema terá recebido influências também de tradições orais, de cunho mais popular e difundidas muitas vezes pelas pregações das ordens mendicantes. Por outro lado - e esse é o ponto que gera uma segunda complexidade - é preciso ter em conta que, sem um texto de base, a imagem do Juízo final jamais poderia ter sido desenvolvida. Mais: sem esse texto de apoio, ela jamais seria plenamente compreendida. É preciso ainda ter em conta que a linguagem das Escrituras é fundamentalmente visionária e metafórica, o que poderia dificultar a sua representação figurativa de modo claro e inequívoco para os fiéis. Ademais, os textos escriturais, que tratam do julgamento por vir, não apresentam uma ordem de eventos estabelecida, a partir da qual seja possível retirar uma 
composição específica e ordenada. Isso obrigou os artistas a buscar formas de representação que simplificassem a visualização da cena.

Indo-se além da questão didática, qual o papel específico que se esperaria de uma obra representando o Juízo final na Idade Média? Doutrinar, sim, mas a respeito exatamente de quê? A resposta pode ser encontrada nos textos medievais mesmo. Com efeito, como escreveu São Hugo de Lincoln ao Rei João, no século XII,

[...] A consciência do homem deveria continuamente lembrá-lo das lamentações e dos tormentos intermináveis dessas misérias. Dever-se-ia manter a lembrança dessas dores eternas na mente do homem todo o tempo. [...] imagens assim eram muito corretamente colocadas na entrada das igrejas. Assim, o povo entrando para rezar por suas necessidades seria lembrado dessa necessidade maior do que todas (Apud BEVINGTON, 1985, p.39).

As representações do Juízo final possuem, portanto, uma função social (e individual) bastante peculiar: elas deveriam suscitar nos fiéis o temor do julgamento - e, nesse sentido, a inclusão da cena da psicostasia poderia atuar como um elemento essencial. O mesmo se pode afirmar com relação à representação das próprias punições infernais, como será melhor comentado a seguir. Sobre o medo do julgamento, comenta o historiador francês Émile Male, tratando especificamente dos relevos esculpidos nos tímpanos das catedrais francesas:

As cenas do Juízo final esculpidas nos pórticos das igrejas moviam as almas dos homens mais profundamente do que podemos imaginar. Elas não eram vistas com mentes livres de ansiedade, pois os fiéis, passando pela porta, acreditavam que a cena sobre suas cabeças poderia a qualquer momento tornar-se um fato, e a trombeta do anjo soar em seus ouvidos (MÂLLE, 1972, p.355-356).

Como forma de reforçar essa ideia, muitas das pinturas italianas com o tema, assim como os tímpanos, foram realizadas na parede oposta à abside e ao altar. Deve-se recordar que as igrejas, desde os primeiros tempos, seguiam preferencialmente a orientação leste-oeste. A abside com o altar colocada na extremidade leste foi uma forma encontrada pelos primeiros cristãos para relacionar o sol nascente a Cristo, a luz do mundo, conforme afirmado pelas Escrituras ${ }^{17}$. Em contraste, o sol poente, no mundo ocidental, era entendido como uma metáfora do fim e da morte. Mais do que apropriado pareceria então uma representação do Juízo final nessa parede, seja em relevo no tímpano da portada, seja como pintura no interno, como seria mais comum nas igrejas italianas. As pinturas preenchiam função semelhante à dos tímpanos externos. Segundo Otto Demus, "[As pinturas] ocupariam normalmente toda a parede, um poderoso lembrete sobre as Últimas Coisas [morte, julgamento, Paraíso e Inferno] para a congregação, enquanto deixava a Igreja" (Apud BEVINGTON, 1985, p.40). 
A pequena diferença de posicionamento das imagens na Itália e na França traz, sem dúvida, uma diferença com relação à significação e à função específicas da cena. Sendo colocada na face interna da parede de entrada, a pintura seria vista especialmente quando da saída do fiel da igreja, e possivelmente se esperaria que sua mensagem fosse levada com ele; esta seria uma forma de fazê-lo meditar sobre as questões referentes ao fim dos tempos em sua vida cotidiana. Nas catedrais francesas, por outro lado, o tema do Juízo final seria recordado pelo fiel especialmente durante sua permanência no interior da igreja, uma vez que seria visto no momento do ingresso no espaço religioso. De uma forma ou de outra, a intenção desse tipo de imagem seria a de auxiliar o fiel a se preparar de forma mais adequada para a morte e para o posterior juízo, ao fazê-lo meditar sobre os destinos possíveis após a morte e também após o fim dos tempos, visando a mudanças de comportamento enquanto ainda haveria tempo, como fica claro pela inscrição que se encontra no tímpano do portal da Igreja abacial de Sainte-Foy, em Conques: O peccatores transmutetis nisi mores durum iudicium scitote futurum (Apud CHRISTE, 2000, p.07). Esse papel de aviso e de preparação para a morte pode ter sido exacerbado ao longo do tempo, influenciando a forma como o Juízo final seria representado; isto poderia ser relacionado em especial à progressivamente maior participação leiga na religião cristã, que vinha ocorrendo ao menos desde o século XII, e que se intensificou nos séculos XIII e XIV.

O tema do Juízo final possui grande destaque na arte ocidental pelo menos desde o século XI, especialmente com os relevos nas portadas das catedrais francesas. Na Itália, também é desse período a mais antiga representação do tema, o afresco da Basílica de Sant'Angelo in Formis (Figura 2). Nesse momento, a composição costumava sofrer poucas variações: no centro o Cristo juiz; de um lado os eleitos no Paraíso, de outro os condenados que se dirigem ao Inferno; ao redor do Cristo, grupos de santos. Nessas imagens mais antigas do Juízo final, Paraíso e Inferno, em geral, são apenas sugeridos, e não efetivamente representados - o primeiro com a imagem do seio de Abraão ${ }^{18}$ (figura 5) ou do cortejo de eleitos diante de uma porta, o segundo aludido pela Boca do Inferno; o destaque, nesses exemplos, recairia especialmente sobre o julgamento, sobre a separação entre os eleitos e condenados. Essas representações possuiriam especialmente uma função de memória, de recordar os fiéis de que haverá um julgamento futuro, e que devem, portanto, se preparar para ele ${ }^{19}$. 


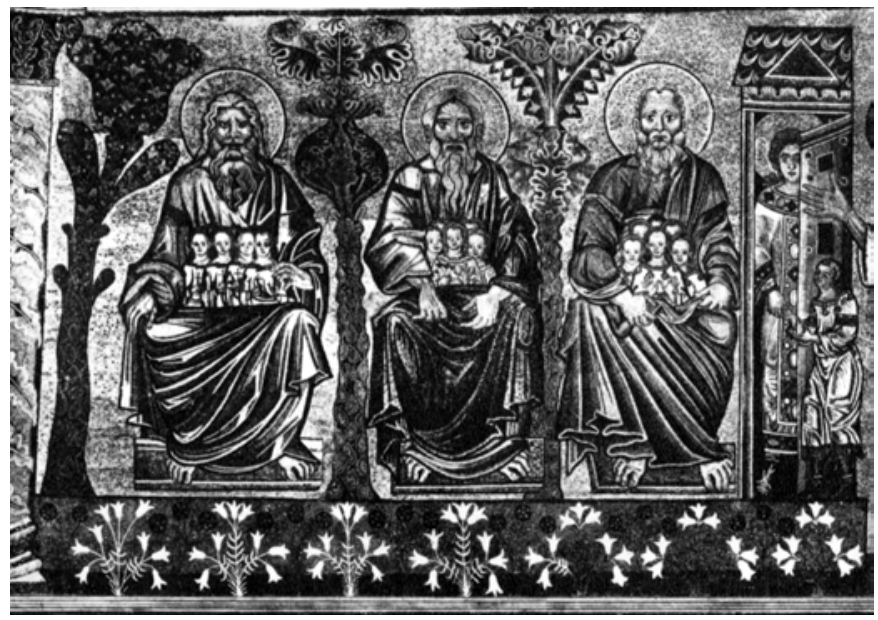

FIGURA 5 - Coppo di Marcovaldo. Juizo final, detalhe do seio de Abraão, ca. 1270-1290. Florença, Batistério de San Giovanni. Procedência da fotografia: GARZELLI, A. Per una lettura del Giudizio universale nel Battistero di Firenze. Romanico mediopadano e romanico europeo. Atti del Convegno internazionale. Modena, 1977

No momento em que a essas duas instâncias passou a ser dado um destaque visual maior, até que se chegou, em meados do século XIV, ao desmembramento completo de ambas como cenas autônomas e complementares ao Juízo final mesmo, criou-se também uma mensagem mais direta e efetiva: a imagem agora não apenas recordava o fiel de que em um momento futuro haverá um julgamento; mostravam-se também as possibilidades - irreversíveis, deve-se destacar - de destino após esse mesmo julgamento.

As figurações de Paraíso e Inferno possuem áreas equivalentes em quase todas as representações do Juízo final, seja em painéis ou afrescos em que o tema é desenvolvido em uma cena única, seja em pinturas em que há o seu desmembramento em mais de uma composição - a exceção mais importante, sem dúvida, está no ciclo do Camposanto de Pisa (ca. 1336-1340), em que há somente o Inferno (Figura 6). Percebem-se, porém, diferenças notáveis nos modos como as duas instâncias são representadas.

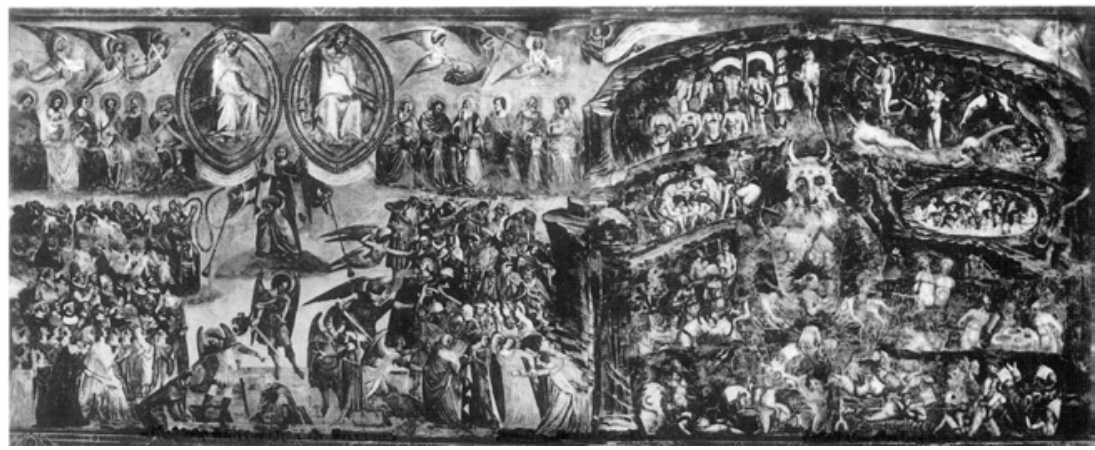

FIGURA 6 - Buonamico Buffalmacco. Juizo final e Inferno, ca. 1336-1340. Pisa, Camposanto. Procedência da fotografia: CARLI, E. La pittura a Pisa. Dalle origini alla 'bella maniera'. Pisa: Pacini, 1994 
Deve-se analisar, primeiramente, as representações em que há uma composição única para o Juízo final, em que as instâncias do Além estão englobadas. Nas obras de influência bizantina - o mosaico de Torcello (último quartel do século XII) e o do Batistério de Florença (ca. 1270-1290) o Paraíso é sugerido, como apenas comentado, como o seio de Abraão (Figura 5), juntamente com os outros patriarcas, geralmente em um ambiente ajardinado, fechado pela porta de entrada do Paraíso; do lado de fora, o cortejo de eleitos, guiado por anjos, se dirige em direção a essa porta.

Nas pinturas de matriz mais caracteristicamente ocidental, por outro lado, encontra-se usualmente apenas o cortejo de eleitos se dirigindo ao Paraíso; sabe-se que são os eleitos porque, além de estarem à direita do Cristo, dirigem usualmente não somente o olhar, como também gestos de devoção, ao Cristo juiz e aos santos que O ladeiam. Em alguns casos, há uma sugestão mais precisa devido à inserção de sua porta de entrada. No painel de Guido da Siena, executado no fim do século XIII (Figura 7), por exemplo, há não somente a porta, mas também São Pedro que recebe o grupo diante da entrada. Não há, porém, indicação do Paraíso per se, nem das recompensas destinadas aos bem-aventurados ${ }^{20}$.

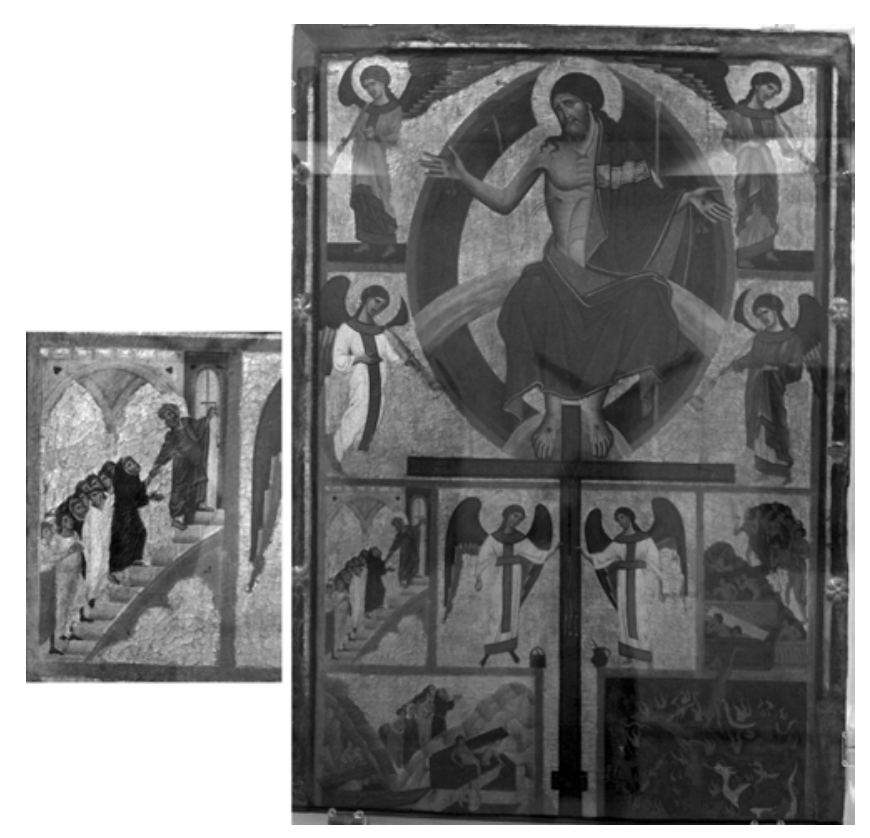

FIGURA 7 - Guido da Siena. Juizo final, fim do século XIII. Grosseto, Museo Diocesano. Fotografias e montagem da autora

Em contraposição aos dois modos de figuração do Paraíso, o Inferno parece ter sido interpretado de forma mais detalhada. Desde o momento em que passou a integrar propriamente a composição do Juízo final - e não sendo apenas sugerido por meio da boca infernal -, as punições do Inferno foram, de modo gradativo, sendo visualmente descritas com mais minúcia, buscando-se também a associação entre os pecados cometidos em vida e as punições infligidas após a morte. O conceito de memória continua sendo válido, mas passou a ser utilizado especialmente conforme a 
acepção agostiniana, esclarecida por Patrick Geary: “A memória era a memória do pecado e de Deus, a memória como distração e como consciência, a ponte entre a perfeição intemporal do Criador e a natureza temporal e múltipla da criatura humana imperfeita" (SCHMITT; LE GOFF, 2002, p.167).

Ao enfatizar a representação do Inferno, como ocorre em várias obras, parece que a intenção da obra seria a de incitar o fiel a rememorar suas faltas e, ao reconhecer nos pecadores punidos na cena seus próprios pecados, perceber os castigos que mereceria.

Poder-se-ia especular que, no momento em que houve o desmembramento do tema do Juízo final, e as instâncias do Além adquiriram autonomia compositiva, esse panorama se alteraria. De fato, uma área consideravelmente maior para a representação do Paraíso tornava plausível a espera por um desenvolvimento iconográfico dessa instância do Além. Isso, entretanto, não ocorreu - ou, pelo menos, não de modo equivalente ao que aconteceu na área infernal. A partir de meados do século XIV percebe-se uma maior proeminência na representação dos pecados capitais no Inferno. Isto já ocorria em obras anteriores, como no afresco de Giotto em Pádua, em que vários dos pecados são passíveis de identificação, mas em períodos posteriores o destaque passou a ser cada vez maior. A historiadora americana Gail Elizabeth Solberg comenta que, nos ciclos do Camposanto de Pisa e da Collegiata de San Gimignano, os artistas buscaram um maior rigor na representação desses pecados, devido possivelmente às dimensões que o Inferno ganhava como obra autônoma (SOLBERG, 1991, p.813) - e, talvez, também em função da preocupação didática e da busca de intimidação dos fiéis; as pinturas deixam de ser somente uma incitação à confissão, mas indicam também ao espectador de forma clara quais pecados ele deveria evitar. Sobretudo, não se trata mais de um memento do julgamento; é a explicitação da forma mais direta possível dos dois destinos póstumos possíveis do homem, com todas as suas consequências.

Percebe-se também que, nos ciclos com o tema do Juízo final executados na segunda metade do Trecento, há uma preocupação maior de facilitar a leitura da imagem por parte dos fiéis. Isso ocorre não apenas com a inserção de elementos de maior apelo popular, mas também por meio da escrita. No afresco de Taddeo, por exemplo, não apenas há a reprodução dos pecados como eles são explicitamente indicados por inscrições: la superbia, la vidia, la lussuria, la varitia - soberba, inveja, luxúria e avareza; o historiador italiano Peccori identificava em 1853 outras inscrições: em uma delas podia ser lida a palavra gola, em outra a expressão gli accidiosi; isso indicaria que algumas das legendas da pintura foram perdidas com o passar do tempo (Cf. NORMAN, 1995, p.182), certamente por terem sido pintadas a secco depois da conclusão do afresco. Alguns pecadores específicos também são identificados por essas inscrições: avaro, golosi, usuraio, além de outros tipos de pecado como o falso testimonio, que também poderiam ser incluídos em algumas das categorias de pecados capitais. 
Opção semelhante fez Nardo di Cione em seu ciclo na Capela Strozzi, na Igreja de Santa Maria Novella, em Florença (ca. 1357). Para tornar mais claro o Inferno (Figura 8), evidentemente inspirado no canto dantesco da Commedia, o artista incluiu sentenças que explicavam quais pecadores eram punidos naqueles círculos específicos: Qui sono puniti gli impostori e gli indovini; Qui si puniscono coloro che poetero (sic) consiglio fraudolento; Qui sono puniti gli iracondi e accidiosi, dentre outras. Incluiu também tipos específicos de pecadores, uma vez mais os identificando por meio de inscrições: ippocriti, alchimisti, eresiarchi. E, originalmente, o Inferno do Camposanto também possuiria inscrições para identificar seis dos pecados capitais (BASCHET, 1993, p.304); a soberba, segundo Baschet (1993, p.298), estaria representada na figura mesma do Diabo, assim como nas figuras por ele punidas.

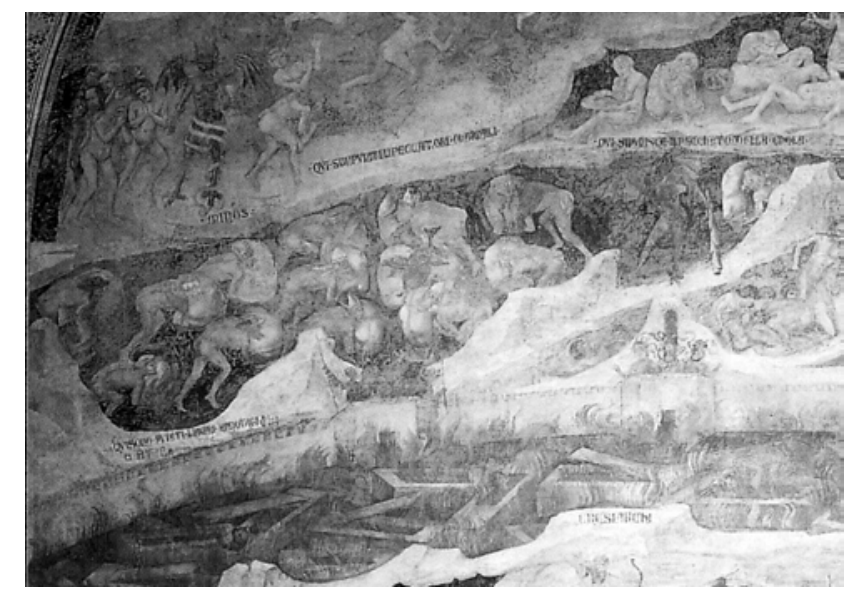

FIGURA 8 - Nardo di Cione. Detalhe do Inferno, ca. 1357. Florença, Igreja de Santa Maria Novella. Procedência da fotografia: ZUFFI, S., CREPALDI, G. e LORANDI, F. Affreschi da Giotto a Michelangelo.

Milão: Mondadori, 2002

Percebe-se, portanto, que, ao menos nos exemplos dos ciclos de Pisa, de San Gimignano e da Capela Strozzi - mas a questão poderia ser estendida a inúmeras outras obras que também possuem inscrições -, a imagem pode ser lida e interpretada de modo mais literal, através dos tituli que definem os pecadores. À parcela da população letrada, mesmo que não necessariamente expressiva, a compreensão da obra ficaria ainda mais simples e evidente tendo em vista o fato de que as legendas, em geral, foram escritas não em latim, mas na língua vernácula do povo. E, retomando por um momento a discussão com relação à máxima de São Gregório, os letrados poderiam ler para os analfabetos essas inscrições, reforçando desse modo a percepção e a compreensão que os iletrados poderiam ter da cena.

Particularmente no ciclo pisano, as inscrições não se resumiam à identificação dos diversos tipos de pecadores representados no afresco do Inferno; havia um memento constante dirigido aos fiéis, através das inscrições que ainda eram legíveis no fim do século XIX: tanto no afresco do 
Trionfo, como nos do Juízo final e do Inferno, há a ênfase, por meio dos textos, na necessidade de se olhar atentamente as imagens para absorver de modo adequado o seu conteúdo, técnica recorrente nos preceitos da ars memoria difundidos no século XIV. Deve-se destacar também que, no ciclo do Camposanto, havia originalmente epígrafes tanto em vulgar como em latim. Percebe-se, assim, como os fiéis - a quem a obra se destinava - eram divididos em pelo menos três categorias: os analfabetos, aqueles que saberiam ler somente o vulgar, e aqueles que leriam também o latim (Cf. BOLZONI, 2002, p.23). Dessa forma, a obra propiciaria níveis diversos de comunicação, "selecionando as mensagens diversas que uma mesma imagem pode transmitir de acordo com o nível cultural (e social) do destinatário" (BOLZONI, 2002, p.22).

No entanto, mesmo aqueles que não conseguissem ler as diversas inscrições, ou não tivessem alguém por perto para as ler para ele, poderiam ser capazes de compreender a mensagem da obra. Várias dessas pinturas mostram, com efeito, a associação didática entre os tipos de pecados e as penas específicas a eles aplicadas, prática corrente nas representações do tema, e já presente em modelos anteriores. Essa associação já era expressa nas visões do Além. Nos relatos sobre as punições das almas no Além, com efeito, encontra-se, muitas vezes, uma relação direta e evidente entre o castigo infligido e pecados bastante específicos cometidos em vida. O historiador Michael Goodich, por exemplo, menciona um relato do século XIII que narra a história de um clérigo que passava por uma floresta na qual seu defunto senhor costumava caçar:

Envolto por uma densa nuvem, foi separado de seus companheiros e levado pelo cavalo para um grande palácio no qual seu senhor estava sentado em uma cadeira em chamas, usando uma coroa flamejante, sofrendo pelas mãos de suas próprias vítimas [...].Os cervos que o chifravam eram os mesmos que ele havia esfolado e de que havia retirado os chifres na mesma floresta. Os dois cães caçadores negros que dilaceravam sua pele pertenceram a dois homens que havia enforcado porque se recusaram a permitir que seus cães caçassem para ele na floresta. E o jovem que o golpeava em seu trono, agarrando sua coroa e esfaqueando-o no coração, era o mesmo homem que ele havia matado com suas próprias mãos na floresta. A floresta agora servia de local para seu próprio castigo retribuidor (GOODICH, 1995, p.109).

Como se pode perceber, o pecador nesse relato é atormentado por aqueles a quem condenou em vida, e os castigos estão diretamente relacionados a esses eventos específicos. A expressão "castigo retribuidor", no texto, é sem dúvida bastante significativa.

Ao se buscar uma representação visual das punições nas regiões infernais, tamanha especificidade foi usualmente abandonada; agora, com efeito, a obra se dirigiria a um público mais amplo, com temas mais gerais, que fossem de mais fácil compreensão. Daí venha talvez a ênfase na representação dos pecados capitais, cujas características seriam bem conhecidas pelos fiéis. Desse modo, a mensagem seria mais facilmente compreendida. 
É possível que a representação iconográfica dos pecados capitais tenha derivado dos penitenciais, que foram bastante comuns ao menos até o fim do século XII, e que continuaram exercendo influência sobre os manuais de confissão posteriores. De fato, nesses chamados Libri paenitentialis havia uma tendência, desde seu surgimento, no século VI, a se aplicar a chamada cura pelo contrário, baseada em um antigo provérbio: "curem-se os contrários com os seus opostos" (MUZZARELLI, 1980, p.215) ${ }^{21}$. Se o penitente havia cometido o pecado da gula, que fizesse jejum; se havia praticado a luxúria, que buscasse a castidade; e assim por diante. A questão que pode ser colocada é a de que se alguém está no Inferno, é porque não conseguiu expiar os seus pecados em vida; ou seja, não teria conseguido seguir a cura pelo remédio contrário. Assim, é possível conjeturar a possibilidade de se exacerbar os pecados no Além. Se alguém foi condenado por um determinado pecado, que sofra por causa desse pecado, por causa das consequências desse pecado e mesmo em função desses pecados por toda a eternidade.

A associação entre o pecado e o tipo de purgação, como visto, está presente em diversas visões medievais do Além; em muitas, porém, a punição não é explicada ou simplesmente não é possível estabelecer uma relação direta entre esta e os pecados cometidos em vida. O Apocalipse de São Paulo, por exemplo, menciona continuamente ao longo do texto que os pecadores "pagam suas penas sem cessar”, esclarecendo qual o pecado cometido. Não há, no entanto, relação entre o tipo de pecado e a punição, embora o texto afirme igualmente de um pecador que "agora ele é recompensado de acordo com sua iniquidade e suas ações" (Apud GARDINER, 1989, p.38). Devese considerar, certamente, que o Apocalipse de São Paulo é uma das mais antigas descrições do Além que chegou aos dias atuais; visões posteriores concederiam muitas vezes uma atenção maior não apenas ao pecado, mas ao esclarecimento também dos motivos porque alguém que tivesse em vida cometido esse pecado deveria ser punido daquela forma ${ }^{22}$. Nesse sentido, a Commedia de Dante seria o modelo por excelência. O poema dantesco, de fato, se insere em uma longa tradição de descrição de viagens ao Além. Dante certamente conhecia a maior parte dessas descrições do Além, assim como outras histórias transmitidas somente de forma oral (JACOFF, 2007, p. 69) ${ }^{23}$.

A Visão de Tundale, por exemplo, descreve as punições sofridas especialmente pelos monges luxuriosos, embora não se limite a eles, incluindo qualquer pessoa que tenha tido uma vida desregrada no campo sexual:

Seus genitais são consumidos por dores diversas uma vez que não observaram limites [...]. Também seus genitais, que não se retraíram da proibida luxúria das relações sexuais, são ou cortados fora ou produzem bestas ferozes para aumentar sua dor [...]. Embora essa dor seja especialmente para aquele que são chamados a serem religiosos e não o são; no entanto aqueles que se corrompem pela luxúria imoderada também sofrem essa punição. Por essa razão [explica o guia a Tundale] você não poderá evitar esse castigo, uma vez que enquanto você estava em seu 
corpo não temeu ter relações sexuais sem moderação (Apud GARDINER, 1989, p. 171).

A punição, assim, está de alguma forma relacionada ao tipo de pecado cometido em vida. Muitas das descrições encontram um equivalente visual nas representações do Inferno da tradição medieval, embora não se deseje discutir aqui qual modelo teria surgido inicialmente. Por exemplo, no caso dos gulosos as figuras foram postas, tanto no afresco de San Gimignano como no do Camposanto de Pisa, diante de uma farta mesa, impedidas pelos demônios de devorar o banquete que lhes é apresentado - o chamado suplício de Tântalo; no afresco de Giotto em Pádua, pelo contrário, aos gulosos são continuamente fornecidos alimentos através de um cano que lhes é enfiado na boca (Figura 9). Talvez nos dois primeiros exemplos mencionados se perceba com maior clareza a noção que se encontra nos livros penitencias - contraria contrariis sanantur. Nesse caso, porém, jamais haverá a possibilidade de cura. Por fim, Taddeo di Bartolo representou o avaro sendo enforcado com um saco de dinheiro, enquanto o usurário é obrigado a engolir moedas de ouro que são defecadas em sua boca por um demônio. Percebe-se então que, através dos elementos iconográficos que compõem a imagem, a mensagem específica da obra - quais pecados cometidos em vida mereceriam que formas de punição no Além - se torna clara, independente da classe social a que pertence o observador ou de sua capacidade de leitura; a imagem, desse modo, consegue desempenhar de modo inequívoco sua função primordial.
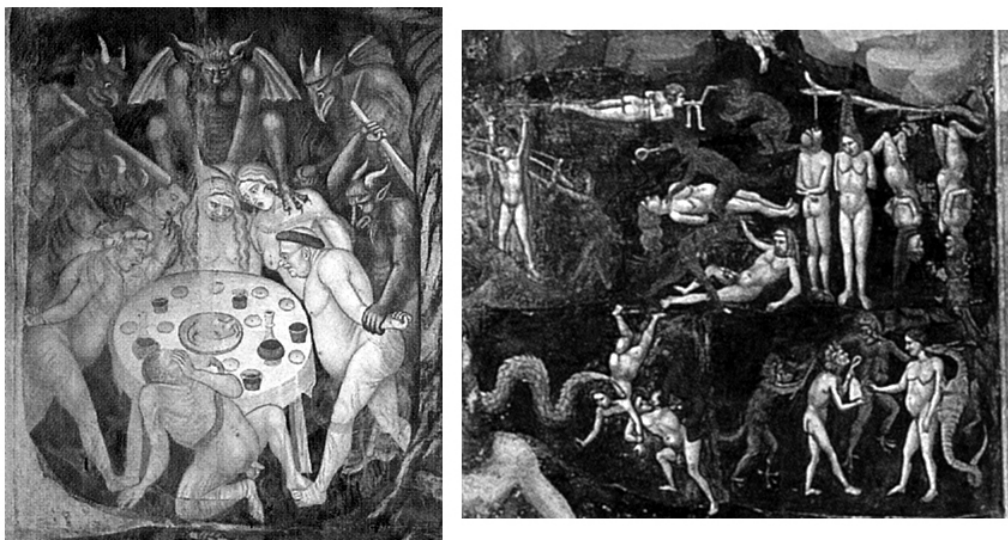

FIGURA 9 - Taddeo di Bartolo. Inferno, detalhe dos gulosos, ca. 1393. San Gimignano, Collegiata; Giotto di Bondone, Juizo final, detalhe do Inferno, 1305-1307. Pádua Capela Scrovegni. Procedência das fotografias: IMBERCIADORI, J.V., e TORRITI, M. La Collegiata di San Gimignano. Poggibonsi: Nencini, s/d e CHRISTE, Y. Il Giudizio universale nell'arte del Medioevo (trad. Maria Grazia Balzarini). Milão: Jaca Book, 2000. Montagem da autora

No Inferno, portanto, os castigos continuaram sendo minuciosamente descritos, potencializando a mensagem da cena não somente pela inclusão das inscrições, como também pelo tamanho da composição. Não há no Paraíso, em contrapartida, o equivalente das benesses sendo 
apresentadas. Pelo contrário, nos exemplos de afrescos remanescentes em que foi feito esse desmembramento das instâncias do Além - os ciclos de Nardo di Cione e de Taddeo di Bartolo, além do afresco atribuído a Giotto no Palazzo del Bargello (ca. 1336-1337) - a representação do Paraíso se dá como o grande cortejo celeste: fileiras de santos que contemplam o Cristo e a Virgem posicionados lado a lado e acima de todos os outros santos, nos exemplos de San Gimignano e de Santa Maria Novella, ou somente o Cristo, no exemplo do Bargello. Não há representação evidente das recompensas que aguardariam aqueles escolhidos pelo Cristo juiz, apesar dos subsídios fornecidos pela teologia. Por que isso ocorre?

É possível conjeturar que a própria situação política da Toscana dos séculos XIII e XIV tenha exercido influência sobre essa ênfase no Inferno nas representações visuais do tema do Juízo final. Havia nesse momento uma espécie de culto à violência, explicado pela historiadora francesa Élizabeth Crouzet-Pavan. A autora cita como exemplo a crônica do florentino Dino Compagni (ca. 1260-1324), que "conta como, dia após dia, o ódio e as batalhas de ruas, a vingança e as dilacerações do corpo civil animavam Florença” (CROUZET-PAVAN, 2004, p.12). Cita ainda que, ao menos desde os últimos quartéis do século XIII, tornara-se comum nos comuni italianos a representação figurativa, "no mais público dos espaços públicos” (CROUZET-PAVAN, 2004, p.76) - ou seja, nas praças ou nos palácios de governo -, dos condenados por crimes chocantes, dos traidores e dos derrotados políticos. "A falta era estigmatizada em todo seu horror, a vergonha e a memória eram conservadas, perpetuadas (...)" (CROUZET-PAVAN, 2004, p.76). Essas representações seriam renovadas periodicamente, conforme novos criminosos fossem julgados, de modo a manter sempre vívida a memória das punições.

A violência, ainda para Crouzet-Pavan (2004, p.90), foi nesse período

Uma forma comum de expressão do político, o uso dominante de uma cultura, em suma uma prática necessária e identificadora. Nesse sentido, a violência e o conflito surgem como o motor sempre ativo da história da Itália no século XIII. ${ }^{24}$

Ainda relacionado a isso, é preciso recordar também que as punições eram realizadas de modo a poderem se tornar espetáculos públicos, com o objetivo de incutir medo naqueles que as observavam (Cf. BARNES, 1998, p.18).

Dessa forma, essa realidade teria sido incorporada à tradição iconográfica do Inferno. Ao menos em um dos exemplos discutidos sucintamente aqui, é evidente a influência que a vida contemporânea teve sobre a representação visual do Juízo final, particularmente no que se refere a esse espetáculo da violência. No afresco de Giotto, em Pádua, são mostrados instrumentos de tortura judicial coevos, e as punições representadas são as mesmas concedidas aos infratores da época. Torturas como o esmagamento de ossos, mãos decepadas e esmagamento da espinha. Há 
também nesse afresco outras alusões a castigos comuns na Toscana do Trecento, como figuras penduradas de cabeça para baixo, o que era considerado uma forma bastante vergonhosa de punição capital na época (Cf. BARNES, 1998, p.18). Aos fiéis, capazes de identificar os objetos e de recordar a dor causada nos condenados a sofrer esses suplícios, as punições se tornavam bastante reais e ainda mais convincentes.

Visando, portanto, a uma facilidade de reconhecimento por parte dos fiéis que se deparassem com as cenas infernais, foi necessário que as figurações do Inferno, por mais irreais que fossem, partissem sempre da realidade deste mundo. Tomem-se, por exemplo, os instrumentos de tortura utilizados pelos demônios. Ao contrário do que se poderia talvez imaginar, em muitos dos exemplos, literários ou visuais, são utensílios comuns, utilizados habitualmente pelo povo medieval em suas atividades cotidianas. Como explica Barbara Palmer, "são as ferramentas da terra, transferidas por suas ligações semânticas dos implementos necessários para a realização de um trabalho e o conceito de trabalho sendo tortura literal” (DAVIDSON; SEILER, 1992, p.25) ${ }^{25}$.

Assim, instrumentos utilizados habitualmente na agricultura, como arados e forcados, transformaram-se em meios para a tortura nas regiões infernais; serrotes são usados para desmembrar corpos; ganchos de cozinha bastante comuns no período, que eram utilizados para provar a comida enquanto esta cozinhava em grandes caldeirões, passaram a ser utilizados pelos demônios para guardar os condenados no Inferno. Em muitas representações esses mesmos ganchos foram utilizados para dar estocadas no que parece estar sendo cozinhado nos caldeirões infernais, bastante próximos aos empregados em qualquer casa medieval. Ironicamente, a "comida" preparada agora seriam os próprios torturados, que se debateriam dolorosamente sem nada poder fazer. Comenta Davidson ainda que, no século XIV, inventou-se um novo tipo de fornalha, assim como as técnicas para se fazer ferro fundido. "Quase imediatamente (...) a tecnologia do alto-forno foi adaptada à iconografia do inferno e às punições dos viciosos e dos condenados” (DAVIDSON; SEILER, 1992, p.54).

Há outra possibilidade de explicação para a iconografia do Paraíso, singular quando confrontada com a elaboração do Inferno não somente no mesmo momento, como em exemplos que integram o mesmo ciclo de afrescos. De fato, se há inúmeras formas de punições possíveis - o mal possui uma "diversidade sem fim”, escreve Crouzet-Pavan (2004, p.117) -, haveria uma única recompensa para os eleitos, tão especial a ponto de contrabalançar essa disparidade iconográfica: a contemplação eterna do Criador. Isso é descrito por autores diversos, e mesmo Dante em sua Commedia explicita que os céus de seu Paradiso se referem a graus diversos de beatitude; quanto mais distante do centro inundado de luz, menor a bem-aventurança do eleito. Se iconograficamente, portanto, a representação do Paraíso possui um interesse muito menor do que o Inferno, teologicamente ela apresentaria a maior de todas as recompensas possíveis. 
É preciso considerar ainda outro ponto. Afirma Jérome Baschet que

O desenvolvimento da iconografia do inferno não deve ser interpretado como o sinal de uma acentuação do medo da danação. Porque a imagem do Inferno não está jamais isolada e o medo do inferno não é um fim em si. ${ }^{26}$

Essa ênfase maior no Inferno, entretanto, poderia estar relacionada também à necessidade de levar o fiel à conversão pelo medo. Como escreve o próprio Baschet (Apud MARTIN, 1996, p.87), “o Inferno é um espelho que reflete para o sujeito a imagem de um eu culpado". De fato, é fundamental, ao contemplar uma representação do Inferno, que o espectador se reconheça como uma vítima potencial dos castigos que são figurados na cena.

Esse ponto reforça outra questão. As razões para a crescente importância do Inferno nas composições do Juízo final podem residir também no progressivo aumento da participação leiga nos assuntos religiosos, assim como nas pregações das ordens mendicantes, que buscavam uma conversão dos fiéis por meio de imagens mentais - e visuais - mais fortes. Incultos e, muitos deles, iletrados, deveriam ser persuadidos sobre qual caminho seguir mais pelo medo do que pelo convencimento. Segundo Santo Anselmo, apenas quando tomado pelo medo da condenação eterna é que o homem poderia ser efetivamente levado ao arrependimento (Cf. BEVINGTON, 1985, p.38).

Nesse sentido, escreve Barnes (1998, p.18) sobre o afresco de Giotto na Capela Scrovegni: “essa região inferior do afresco [o Inferno] foi realizada para fascinar e ser estudada, certamente com a esperança de que alguma lição pudesse ser aprendida". Não apenas isso: concedendo especial atenção ao Inferno, poder-se-ia enfatizar também o papel intercessor da própria Igreja - apenas através dela seria possível escapar da condenação para além dos tempos. Essa é uma questão de grande relevância quando se discute as funções de uma imagem com o tema do Juízo final. A elaboração particularizada dos castigos teria, assim, a função de assustar o fiel e prepará-lo para o juízo. Conforme a afirmação das Escrituras, necessário é estar sempre atento, pois não se sabe quando chegará o fim dos tempos e, por consequência, o julgamento final ${ }^{27}$.

De acordo com o raciocínio desenvolvido até agora, o mais importante não seriam as recompensas que os cristãos poderiam receber no Paraíso, mas sim os castigos eternos a que certamente seriam submetidos após o julgamento. Assim, a meticulosidade empregada na descrição das punições infernais, que enfatizariam o medo da danação especialmente quando a representação do Inferno estivesse associada ao tema mais amplo do Juízo final, incitariam "o espectador a agir de forma cristã" - conforme já o afirmara Baschet -, de modo a se conseguir evitar a condenação para além dos tempos. E, nesse sentido, as imagens representando as torturas infernais funcionariam como um reforço muito mais ativo e efetivo do que qualquer outra descrição, como já o haviam 
afirmado, de resto, São Boaventura e Santo Tomás de Aquino. Eloquente, nesse sentido, era uma das inscrições que acompanhava originalmente o afresco do Inferno pisano:

Ó pecador que nessa vida estás/ Evolvido estás pelas coisas mundanas/ Ponha a mente fixa nestas ásperas figuras/ Que neste obscuro Inferno criam problemas./ Assim como elas são assim serás/ Se não te arrependes do mal que fizeste. ${ }^{28}$

Percebe-se, uma vez mais, a importância das inscrições para a adequada interpretação dessas imagens. Pois, como esclarece Baschet (1993, p.239-330), "uma coisa é ver a imagem do inferno; e é outra imaginar a si próprio relacionado a um tal destino".

Nesse ponto, pode-se considerar que também a composição simplificada do Paraíso (Figura 10) nos ciclos de afrescos se ligaria a esse esquema mais amplo: a vasta galeria de santos que se abria diante dos olhos dos fiéis tornaria mais fácil a prece por um santo intercessor que, talvez, pudesse estar representado entre os outros, uma vez que eram incluídos nessas grandes cenas aqueles santos mais populares - identificados por seus atributos iconográficos - e, portanto, de maior apelo aos espectadores. Sua presença nas representações poderia suscitar a devoção dos fiéis, de modo que estes lhes dirigissem preces visando a sua intercessão para o perdão de suas faltas. Na religiosidade laica do século XIV havia de fato um

Forte senso de reciprocidade entre, por um lado, o poder espiritual da própria imagem e, por outro, o comprometimento e o fervor religiosos dos devotos das imagens. Esta reciprocidade surgiu na crença mesma na intercessão dos santos. Assim, alguém rezaria para que o santo intercedesse diante de Deus a seu favor. Em troca, o requerente prometeria realizar alguns atos pios (NORMAN, 1995, p.181).

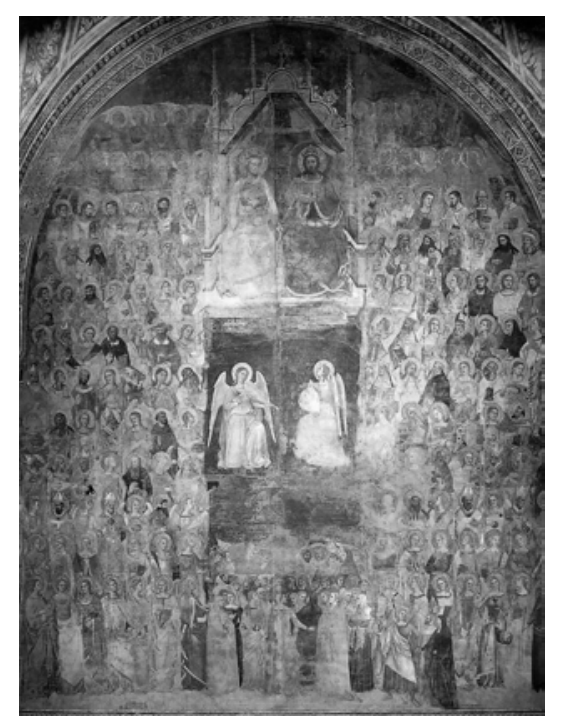

FIGURA 10 - Nardo di Cione. Paraíso, ca. 1357. Florença, Igreja de Santa Maria Novella.

Procedência da fotografia: ZUFFI, S., CREPALDI, G. e LORANDI, F. Affreschi da Giotto a Michelangelo. Milão: Mondadori, 2002 
É preciso, entretanto, ponderar outra questão. As representações visuais do Juízo final são diversas de outras imagens religiosas ao menos em um ponto: boa parte dessas últimas poderia ser classificada como imagem devocional, seja representando o Cristo, a Virgem ou um santo, e mesmo cenas religiosas diversas. O Juízo final é um tema diverso: ele se refere a um evento futuro, que ninguém sabe exatamente como irá ocorrer; é um evento que ocorrerá para todos, não somente para aqueles representados nas cenas, mas para cada pessoa que se coloca diante da cena. O tema, ademais, ganha maior proeminência em relação às figuras representadas. Uma primeira razão poderia ser o fato de que há um grande número de personagens, o que em alguns casos impossibilitaria a individualização dessas personagens secundárias, ainda que possam ser claramente identificadas como santos. Sem dúvida, as figuras principais são perfeitamente discerníveis, especialmente o Cristo juiz, mas também alguma outra figura santa que possa despertar um particular sentimento devoto no fiel, como a Virgem Maria, São João Batista ou mesmo o arcanjo Miguel ou outros santos que, como apenas visto, poderiam exercer uma maior atração sobre os fiéis que observassem a cena. A devoção a essas figuras, no entanto, estaria relacionada necessariamente ao tema principal, que é o julgamento final e o destino post-mortem; a devoção do fiel seria dirigida especialmente a preces visando à intercessão desses santos para que pudessem evitar sua condenação futura - e é por isso que é particularmente comum na Península Itálica a cena da Deesis, em que a Virgem Maria e São João Batista - ou São João Evangelista, como ocorre em alguns exemplos - atuariam explicitamente como intercessores da humanidade diante do Cristo juiz.

O Juízo final, desse modo, com as representações desenvolvidas de Paraíso e Inferno, pode ser considerado tema fundamental para a reflexão humana. A representação de horríveis torturas poderia tirar a mente do fiel de seu natural torpor, permitindo a tomada de atitudes que evitariam a condenação, retomando uma vez mais o que escrevera Santo Anselmo. Evocam-se aqui as palavras do Eclesiástico: "Em todas as tuas obras, lembra-te do fim, e jamais pecarás" (Ecl 7, 36).

Percebe-se, assim, como as representações visuais de temas religiosos diversos - analisou-se a figuração do Juízo final, mas a discussão poderia ser ampliada para qualquer tema - são capazes de dizer muito a respeito não somente da religiosidade, como também da história de uma determinada sociedade. Como escreve Peter Burke (2005, p.58),

Imagens têm sido utilizadas com freqüência como um meio de doutrinação, como objetos de cultos, como estímulo à meditação e como armas em controvérsias. Portanto, elas também são um meio através do qual historiadores podem recuperar experiências religiosas passadas, contanto que eles estejam aptos a interpretar a iconografia. 
Assim como as obras medievais, quaisquer outros tipos de imagem podem cumprir função semelhante: informar não apenas sobre os temas representados nessas obras, as condições sob as quais determinados tipos de imagem foram produzidos, mas também sobre as sociedades que criaram essas mesmas imagens ${ }^{29}$. Compreende-se, portanto, a importância das imagens para uma formação histórica mais completa e abrangente. Independente do período de que se esteja tratando, é fundamental que o historiador perceba que "a cultura histórica não se concebe sem imagem" (RAYNAUD, 1997, p.07).

\section{Agradecimentos}

Agradeço a CAPES por ter me concedido a bolsa PDEE (Programa de doutorado com estágio no exterior), possibilitando desse modo a realização da pesquisa de campo na Itália em 2006, período imprescindível de estudo e amadurecimento para que as pesquisas para a tese de doutorado - da qual esse artigo é um excerto - pudessem ser plenamente desenvolvidas.

\section{Referências Bibliográficas}

ANGHEBEN, M. Les jugements derniers byzantins des $\mathrm{XI}^{\mathrm{e}}-\mathrm{XII}^{\mathrm{e}}$ siècles et l'iconographie du jugement imédiat. Cahiers archéologiques, 50, 2002.

BARNES, B.A. Michelangelo's Last Judgment: the Renaissance response. Berkeley: University of California, 1998.

BASCHET, J. Les justices de l'au-delà. Roma: École Française de Rome, 1993. 1998.

. Paradiso. Enciclopedia dell'arte medievale, v.IX. Roma: Istituto della enciclopedia italiana,

BEVINGTON, D. et alii. Homo, memento finis. The iconography of Just Judgment in Medieval art and drama. Kalamazoo: Western Michigan University, 1985.

BOLZONI, L. La rete delle immagini. Predicazione volgare dalle origini a Bernardino da Siena. Turim: Einaudi, 2002.

BURKE, P. Testemunha ocular. História e imagem (trad. Vera M. dos Santos). Bauru: EDUSC, 2005.

CARLI, E. La pittura a Pisa. Dalle origini alla ‘bella maniera'. Pisa: Pacini, 1994.

CHAZELLE, C.M. Pictures, books, and the illiterate: Pope Gregory I's letters to Serenus of Marseilles. Word and Image, v.6, n.2, 1990. 
CHRISTE, Y. Il Giudizio universale nell'arte del Medioevo (trad. Maria Grazia Balzarini). Milão: Jaca Book, 2000.

CROUZET-PAVAN, É. Enfers et paradis. L'Italie de Dante et Giotto, 2a ed. Paris: Albin Michel, 2004.

DAVIDSON, C.; SEILER, T.H. (org.). The iconography of Hell. Kalamazoo: Western Michigan University, 1992.

DUGGAN, L.G. Was art really the 'book of the illiterate'?. Word and Image, v.5, n.3, 1989

FRUGONI, C. Altri luoghi, cercando il paradiso (il ciclo di Buffalmacco nel Camposanto di Pisa e la committenza domenicana). Annali della Scuola Normale Superiore di Pisa. Série III, v.XVIII, 4. Pisa, 1988.

GARDINER, E. Visions of Heaven and Hell before Dante. Nova York: Italica, 1989.

GARZELLI, A. Per una lettura del Giudizio universale nel Battistero di Firenze. Romanico mediopadano e romanico europeo. Atti del Convegno internazionale. Modena, 1977.

GIZZI, C. (org.). Giotto e Dante. Milão: Skira, 2001.

GOODICH, M. Violence and the miracle in the fourteenth century. Private grief and public salvation. Chicago e Londres: Chicago University, 1995.

GRABAR, E. Byzantine painting (trad. Stuart Gilbert). Nova York, Skira, 1953.

GRUBB, N. Revelations. Art of the Apocalypse. Nova York: Abbeville, 1997.

IMBERCIADORI, J.V., e TORRITI, M. La Collegiata di San Gimignano. Poggibonsi: Nencini, s/d.

JACOFF, R. (org.). The Cambridge companion to Dante, segunda edição. Cambridge: Cambridge University, 2007.

La Peste Nera. Dati di una realtà ed elementi di una interpretazione. Atti del XXX Convegno storico internazionale. Spoleto: Centro italiano di studi sull'Alto Medioevo, 1994.

Le laudi drammatiche umbre dalle origini. Atti del V Convegno di Studio del Centro di studi sul teatro medioevale e rinascimentale. Viterbo, 1980.

LEPPERT, R. Art and the committed eye. The cultural functions of imagery. Oxford: Westview, 1996.

MÂLE, E. The Gothic image. Religious art in France of the thirteenth century (trad. Dora Nussey). Icon, 1972.

MARTIN, H. Mentalités médiévales. XI ${ }^{\mathrm{e}}-\mathrm{XV}^{\mathrm{e}}$ siècle. Paris: PUF, 1996.

MUZZARELLI, M.G. (org.). Una componente della mentalità occidentale: i Penitenziali nell'alto medio evo. Bologna: Pàtron, 1980. 
NORMAN, D. The case of beata Simona: iconography, historiography and misogyny in three paintings by Taddeo di Bartolo. Art History, v.18, n.2, junho, 1995.

. et alii. Siena, Florence and Padua: art, society and religion 1280-1400. Volume 1:

interpretative essays. Londres: Yale University, 1995.

RAYNAUD, C. Le commentaire de document figuré en histoire médiévale. Paris: Armand Colin Masson, 1997.

SCHMITT, J.C.; LE GOFF, J. (org.). Dicionário temático do Ocidente medieval, Volume I. Bauru: EDUSC, 2002.

SOLBERG. G.E. Taddeo di Bartolo. His life and work. Nova York, 1991. Tese (Doutorado em História da Arte) - NYU, 1991.

STURKEN, M; CARTWRIGHT, L. Practices of looking. An introduction to visual culture. Oxford: Oxford University, 2001.

ZUFFI, S.; CREPALDI, G.; LORANDI, F. Affreschi da Giotto a Michelangelo. Milão: Mondadori, 2002.

\section{NOTAS}

${ }^{1}$ Giotto a Padova. Un viaggio giubilare come spirale della salvezza. In: (GIZZI, 2001, p.138).

${ }^{2}$ Destaca Bernardine Barnes, entretanto, que é preciso considerar também que a cena do Juízo final interromperia, de certo modo, a leitura das narrativas das paredes das igrejas, seja porque estaria colocado entre duas cenas sequenciais do ciclo, seja porque excederia a escala dessas imagens; normalmente ocorreriam ambas as situações, enfatiza uma vez mais a autora. Cf. BARNES, 1998, p.08. A intenção, sem dúvida, seria a de apresentar uma imagem poderosa - o que é intensificado por suas dimensões - de modo a exercer uma atração maior nos espectadores.

3 "Nam quod legentibus scriptura, hoc idiotis praestat pictura cernentibus, quia in ipsa ignorantes uident quod debeant, in ipsa legunt qui litteras nesciunt; unde praecipue gentibus pro lectione pictura est” Apud DUGGAN, 1989, p.227-228, nota 01). O trecho provém de uma carta escrita ao bispo Serenus de Marselha, provavelmente em outubro de 600, sobre atividades iconoclastas que o bispo desenvolvia em sua diocese, sem o conhecimento ou a aprovação do papa. Gregório escrevera uma primeira carta ao bispo, possivelmente em julho de 599 sobre o mesmo tema, em que afirmava que "Idcirco enim pictura in ecclesis adhibetur, ut qui litteras nesciunt saltem in parietibus uidendo legant, quae legere in codicibus non ualent" ("Pinturas são usadas nas igrejas de modo que os ignorantes das letras possam pelo menos ler nas paredes por meio da visão aquilo que não podem ler nos livros"). Apud Ibidem. A transcrição completa da primeira carta, assim como da parte mais relevante da segunda, podem ser encontradas em CHAZELLE, 1990, p.139-140. C.M.

${ }^{4}$ Para uma visão da permanência da máxima gregoriana ao longo da Idade Média, ver o artigo de Lawrence Duggan. Recorde-se que mesmo no século XVI, com o Concílio de Trento, essa questão se mantinha ainda atual, especialmente com relação à oposição católica à doutrina protestante, que negava o valor das imagens nos edifícios religiosos.

${ }^{5}$ Lib. III, dist. IX, art. I, q. 2, concl.

${ }^{6}$ Commentum in IV Sent., lib. III, dist. IX, art. 2, sol. 2 ad 3 um.

7 "Sed hoc soliicite fraternitas tua admoneat ut ex uisione rei gestae ardorem compuctionis percipiant et in adoratione solius omnipotentis sanctae trinitatis humiliter prosternantur" ("Mas deixe sua fraternidade avisar [a comunidade] de modo que a partir da visão de acontecimentos passados sintam compunção e se prostrem humildemente em adoração à única Trindade onipotente e santa") Apud CHAZELLE, 1990, p.140.

${ }^{8}$ Sobre esse ponto relacionado à representação do Juízo final, ver a seguir.

${ }^{9}$ Cf. HAWKINS, P.S. Dante and the Bible. In: JACOFF, 2007, p.132.

${ }^{10}$ Esse ponto se aplica especialmente a imagens em igrejas ou outros locais públicos, de fácil acesso, embora seja preciso considerar que o leigo também poderia recordar as explicações quando contemplasse uma imagem devocional privada em sua residência.

11 “(...) quae ad aedificationem imperiti populi factae fuerant, ut nescientes litteras ipsam historiam intendentes, quid dictum sit discerent (...)” Apud CHAZELLE, 1990, p.243. 
${ }^{12}$ A Itália parece ter reinterpretado a cena da psicostasia, uma vez que a pesagem das almas não foi largamente difundida na iconografia do Juízo final. No lugar da psicostasia pode-se encontrar, em alguns exemplos, São Miguel que, segurando uma espada e com o gesto das mãos, indica o local - o dos eleitos ou o dos condenados - para o qual se deve dirigir o corpo apenas ressuscitado.

${ }^{13}$ Echi della lauda nella pittura umbra del XIII e XIV secolo. (Le laudi drammatiche umbre dalle origini, 1980, p.165185)

${ }^{14}$ Le laudi drammatiche umbre dalle origini, 1980, p.166

${ }^{15}$ Le laudi drammatiche umbre dalle origini, 1980.

${ }^{16} \mathrm{O}$ primeiro texto, decerto, é a Bíblia. Deve-se considerar ainda textos apócrifos - como os evangelhos de Pedro e Paulo - e as diversas visões do Além.

${ }^{17}$ Há diversas passagens bíblicas que se referem a Cristo como luz, como a seguinte passagem de João: "Então Jesus tornou a falar-lhes, dizendo: eu sou a luz do mundo; quem me segue, de modo algum andará em trevas, mas terá a luz da vida". 8, 12 .

${ }^{18}$ Para uma discussão mais detalhada sobre o seio de Abraão, ver o artigo de ANGHEBEN, M. Les jugements derniers byzantins des $\mathrm{XI}^{\mathrm{e}}-\mathrm{XII}{ }^{\mathrm{e}}$ siècles et l'iconographie du jugement imédiat. Cahiers archéologiques, 50, 2002

${ }^{19}$ Como explica Patrick Geary, "sob numerosas formas, a memoria estava no centro do cristianismo através de sua injunção eucarística: 'Façam isto em minha memória'” (SCHMITT; LE GOFF, 2002, p.167).

${ }^{20}$ Para um aprofundamento sobre esses e outros modos de representação do Paraíso, ver BASCHET, 1998.

21 "Contraria contrariis sanantur". Cf. MCNEILL, J.T. La medicina per il peccato prescritta nei Penitenziali. In: MUZZARELLI, 1980, p.215.

${ }^{22}$ A Visão do monge de Evesham, no entanto, limita-se a afirmar que "qualquer pessoa que eu via, e por quaisquer pecados fossem punidas, eu percebia claramente tanto a natureza do pecado e o grau de sua punição". Apud GARDINER, 1989, p.204. No Apocalipse de São Pedro, por outro lado, como visto um dos mais antigos textos sobre visões do Além, afirma-se que "aqueles que blasfemaram o caminho da honradez serão pendurados por suas línguas", uma clara associação entre o pecado - cometido por meio da fala - e a punição - centrada na língua pela qual o falar é possível. Apud GARDINER, 1989, p.06.

${ }^{23}$ Cf. PERTILE, L. "Introduction to Inferno". In: JACOFF, 2007, p. 69.

${ }^{24}$ A autora, decerto, não defende em seu livro que a violência nasceu no século XIII. Explica ela que "os conflitos que marcam e transformam a sociedade italiana, fazendo do século XIII o tempo das perturbações civis, nascem certamente nas últimas décadas do século XII" (CROUZET-PAVAN, 2004, p.122). Os motivos desse aumento da violência poderiam se encontrar no crescimento das cidades. A partir de 1170, de fato, "o movimento de inurbamento se acelera" de forma mais ou menos constante em quase todos os centros urbanos da Itália central, não importando se grandes ou pequenos (CROUZET-PAVAN, 2004, p.126).

${ }^{25}$ The inhabitants of Hell: devils. In: DAVIDSON; SEILER, 1992, p. 25.

${ }^{26}$ Image et événement: 1'art sans la peste (c. 1348- c. 1400)?. In: La Peste Nera. Dati di una realtà ed elementi di una interpretazione. Atti del XXX Convegno storico internazionale. Spoleto: Centro italiano di studi sull'Alto Medioevo, 1994, p. 32.

${ }^{27}$ Há diversos textos escriturais que tratam desse tema. A Idade Média privilegiou especialmente a parábola das virgens sábias e das virgens tolas, descrita em Mt 25, 1-13. Nessa passagem, o noivo que está para chegar era interpretado, no período, como Cristo.

28 "O peccator che in questa vita stai/ Involto se' nelle mondane cure/ Pon mente fiso ad queste aspre figure/ Che in questo obscuro Inferno traggien guai./ Chosi' com'elle son cosi serrai/ Se non ti penti del mal che ipso hai”. Apud FRUGONI, C. Altri luoghi, cercando il paradiso (il ciclo di Buffalmacco nel Camposanto di Pisa e la committenza domenicana). Annali della Scuola Normale Superiore di Pisa. Série III, v.XVIII, n.4. Pisa, 1988, p.1570.

${ }^{29}$ Como escreve Burke (2005, p.38), “imagens de haréns de autoria de europeus do século XIX (aquelas pintadas por Ingres, por exemplo) nos dizem pouco ou nada sobre o mundo doméstico do Islã, mas revelam muito a respeito do mundo de fantasia dos europeus que criaram essas imagens, adquiriram-nas ou as puderam observar em exposições ou em livros".

Artigo recebido em 10/2009. Aprovado em 03/2010. 